\title{
1. Urban regions and economic globalization: an introduction
}

We live in the century of homo urbanus. For the first time in human history, half of the world's population will reside in urban regions by 2007 , with the proportion of those urbanized predicted to grow to 60 per cent by $2030 .^{1}$ Indeed, the rate of growth in urbanization will nearly double that of the overall population increase between 2000 and $2030-1.8$ per cent versus 1 per cent. ${ }^{2}$ In contrast, a minuscule 3 per cent of the world's population was urbanized in 1800, 14 per cent in 1900, and 30 per cent in $1950 .{ }^{3}$ In the United States, the first census conducted in 1790 estimated that 5 per cent of the population was urban, with the largest city being New York City with fewer than 50000 people. Urbanization would increase to 11 per cent in 1840, almost 32 per cent in 1900, and about 80 per cent in 2000.4

As a result of global and regional transformations, intergovernmental tensions, social unrest, demographic changes, and a potpourri of other factors, cities are in a state of flux. Many are becoming quite large, especially in the so-called developing world. In terms of nomenclature, the United Nations often refers to the major Western 'industrialized' societies as the more developed countries, the middle-range nations as the less developed, and those suffering from widespread poverty as the least developed. We will use these UN terms throughout this book, although at times we will refer to developed and developing countries as nations of the North and nations of the South. In 2003, there were already 20 megacities with populations exceeding 10 million, and 16 of these were situated in less or lesser developed countries (see Table 1.1). ${ }^{5}$

In contrast to the 20 megacities in 2003 , only New York City had exceeded the 10 million mark back in $1950 .{ }^{6}$ Twenty-two cities now have between 5 and 10 million inhabitants, 370 between 1 and 5 million, and 433 between 500000 and 1 million. $^{7}$ Those countries with the highest Human Development Index figures are more than 70 per cent urbanized, whereas those with the lowest rankings are only 30 per cent urbanized, although one should not overlook the fact that one-quarter to one-third of all urban households subsist in absolute poverty (see Table 1.2 for the degree of urbanization in the developed and developing regions). ${ }^{8}$ In a press release issued by UN-Habitat in June 2001, this UN agency stressed that the "central challenge of the 
Table 1.1 The world's megacities, 2003

\begin{tabular}{llll}
\hline Tokyo & 35.0 & Los Angeles & 12.0 \\
Mexico City & 18.7 & Dhaka & 11.6 \\
New York & 18.3 & Osaka-Kobe & 11.2 \\
Sao Paulo & 17.9 & Rio de Janeiro & 11.2 \\
Bombay & 17.4 & Karachi & 11.1 \\
Delhi & 14.1 & Beijing & 10.8 \\
Calcutta & 13.8 & Cairo & 10.8 \\
Buenos Aires & 13.0 & Moscow & 10.5 \\
Shanghai & 12.8 & Manila & 10.4 \\
Jakarta & 12.3 & Lagos & 10.1 \\
\hline
\end{tabular}

Note: Population in millions.

Source: United Nations Department of Economic and Social Affairs, 2004.

Table 1.2 Urban population as a percentage of total population

\begin{tabular}{llll}
\hline & 1970 & 1995 & 2013 \\
\hline Least developed countries & 12.7 & 22.9 & 34.9 \\
All developing countries & 24.7 & 37.4 & 49.3 \\
Developed countries & 67.1 & 73.7 & 78.7 \\
\hline
\end{tabular}

Source: UN Development Program, 2000.

twenty-first century will be how to make globalization and urbanization work for all the world's people, instead of benefiting only a few.' It noted that one billion urban inhabitants live in inadequate housing. In Africa, only one-third of all urban households have direct access to potable water, and in Asia and the Pacific, only 38 per cent of households are connected to sewerage systems. ${ }^{9}$ Europe and North America were, respectively, 75 per cent and 77 per cent urbanized in 2000, with these percentages expected to increase to 83 per cent and 84 per cent by $2030 .{ }^{10}$ Bigger is not necessarily better, and more Americans have chosen to live in suburbs rather than in central cities, with the 2000 US census ascertaining that 81 million resided in central cities, 119 million in suburbs, and 26 million in 'shadow' areas which are just beyond but not directly connected to the suburbs. Half of all Europeans also live in distinct communities ranging in size from 1000 to 50000 inhabitants.

Without any doubt, the linkages between the local and the global have never been as extensive nor as profound as currently exist in the first decade 
of the new millennium. UN-Habitat asserts that the 'focal point' of globalization 'has invariably been the city, a place of deals and decisions, take-offs and landings - a place less concerned with the rhythms of nature, where everything can be bought or sold, especially one's ideas and labor.' This UN group adds that 'cities no longer stand apart as islands. They are the nexus of commerce, gateways to the world in one direction and focus of their own hinterland. Tied together in a vast web of communications and transport, cities are concentrations of energy in a global field.' Optimistically, UNHabitat concludes that 'in a real sense, the world is completely urbanized, as this force field has the power to convert all places and all people into a productive, constantly adapting unity.' ${ }^{11}$ As a classic example of how cities are affected by aspects of globalization, New York City's population grew by about 1 per cent per year during the 1990s, but this gradual increase masked very dramatic demographic fluctuations as about one-seventh of the population exited the city, only to be replaced by an equal number of overseas immigrants. Today, 36 per cent of New York City's population is foreign born and almost 48 per cent of the population over the age of five speaks a language other than English at home. Some other US cities have even higher concentrations of non-English speakers. For example, Santa Ana, California, which has the fifth largest public school district in that state, has a population composed of 74 per cent who speak Spanish and another 6 per cent who speak a language other than English. ${ }^{12}$

Cities around the world and of all sizes are subject to the vagaries of globalization, and this influence will increase noticeably over the next few decades. The purpose of this book is to examine the economic challenges and opportunities facing urban centers in the first quarter of this century as a result of growing globalization and regionalism, and then to provide some policy insights which will assist urban leaders to enhance for their constituents the positive features of globalization while mitigating, as much as possible, the potentially harmful dimensions.

\section{THE GLOBALIZATION PHENOMENON}

Globalization has been referred to as 'the most important phenomenon of our time. ${ }^{13}$ It connotes a growing interconnectedness among people and societies around the planet. In the book Global Transformations, the authors state that globalization "may be thought of initially as the widening, deepening and speeding up of worldwide interconnectedness in all aspects of contemporary social life, from the cultural to the criminal, the financial to the spiritual. ${ }^{14}$ Nye and Keohane describe globalization as the buzzword of the 1990s, just as 'interdependence' was the buzzword of the 1970s. They define globalization 
as 'a state of the world involving networks of interdependence at multicontinental distances. These networks can be linked through flows and influences of capital and goods, information and ideas, people and force, as well as environmentally and biologically relevant substances (such as acid rain or pathogens).' ${ }^{15}$ Nye and Keohane insist, however, that globalization does not imply universality nor is it rendering nation states obsolete. Kenichi Ohmae disagrees, arguing that the nation state is giving way to region-states, many of which have populations between a few million and 10 to 20 million and are developed around a major urban center. ${ }^{16}$

Various aspects of globalization can be quantified. Since the 1950s, global trade has been growing at about three times the rate of individual national economies, with 6.2 trillion dollars in merchandise trade and an additional 1.5 trillion dollars in commercial services' trade achieved in $2002 .{ }^{17}$ Foreign direct investment (FDI), which provides investors in one country with a controlling interest in a company in another country, has been growing even more rapidly than international trade, with FDI flows topping 1.2 trillion dollars in 2000 alone and with the stock of outward FDI catapulting from 1.7 trillion dollars in 1990 to 6.6 trillion dollars in $2001 .^{18}$ The number of multinational corporations (MNCs) in the world, entities which account for a major segment of trade and FDI globally, has also expanded dramatically from 7000 in the 1960s to roughly 65000 today. These $65000 \mathrm{MNCs}$ control 850000 affiliates which employ 54 million workers worldwide (up from 24 million in 1990) and were responsible for producing 19 trillion dollars in annual sales in 2001, almost three times the value of total international trade. ${ }^{19}$ The foreign affiliates of MNCs currently account for about one-tenth of the world's GDP and one-third of global exports. ${ }^{20}$ Add to this the record levels of international portfolio investments, plus international currency transactions in the range of 1.5 trillion dollars per day, and one begins to understand what economic globalization means in concrete terms. Today, both the international system of production-sharing and stock markets are 24-hour phenomena, following the sun as it rises and sets and beginning with eight hours in Asia and the Pacific, moving on to eight hours in Europe and Africa, and then completing the quotidian cycle with eight hours in the Americas. For example, Sequence Design, a company that produces software to design computer chips, has its headquarters in the United States but maintains other facilities in Japan, India, and the United Kingdom. It maintains a 24-hour production cycle, and as its CEO iterates, 'only time zones are boundaries in my head anymore. There are no geographical boundaries. ${ }^{21}$

In addition, the movement of people across national borders is at unprecedented levels. In spite of the tragic events of September 2001, international tourism returned to record levels in 2002, with 703 million people visiting other countries and spending over 474 billion dollars, compared with 456 
million visitors in 1990 who spent 264 billion dollars. ${ }^{22}$ The Madrid-based World Tourism Organization expects the number of international tourists to top the one billion mark by 2010 and the 1.5 billion level by $2020 .{ }^{23}$ Immigration and refugee flows are also without parallel, and at least 175 million people currently reside in countries different from their place of birth, more than double the figure of $1975 .{ }^{24}$ Immigrants living in other countries constitute 3 per cent of the world's population, and that figure increases to almost 9 per cent in the more developed nations. ${ }^{25}$

Figures 1.1 and 1.2 indicate the degree to which international trade and direct investment activity has increased over the past several decades. Figure 1.3 illustrates the substantial increase in international tourism, and Tables 1.3 and 1.4 show the growth in international immigration and how immigrants have become a much more substantial part of many societies. Figure 1.4 indicates that globalization goes far beyond the economic dimension and is affecting local populations in myriad ways. As James Wolfensohn, President of the World Bank, emphasizes: 'There is no wall. We are linked by trade, investment, finance, by travel and communications, by disease, by crime, by migration, by environmental degradation, by drugs, by financial crises and by terror.' $^{26}$

To illustrate this growing interdependence and its impact on local populations, there is no doubt that individual nations are capable of taking concrete steps toward controlling the use of substances within their respective borders which contribute to ozone deterioration or global warming (Fig.1.4). However, unless other nations, many of which may be located

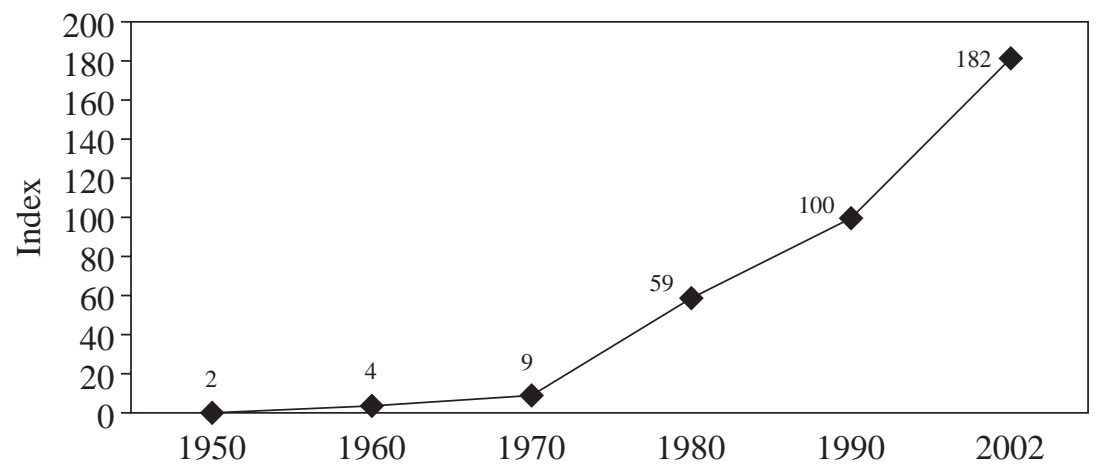

Note: $\quad 1990=100$

Source: $\quad$ World Trade Organization (2003).

Figure 1.1 World merchandise exports in current US dollars, 1950-2002 


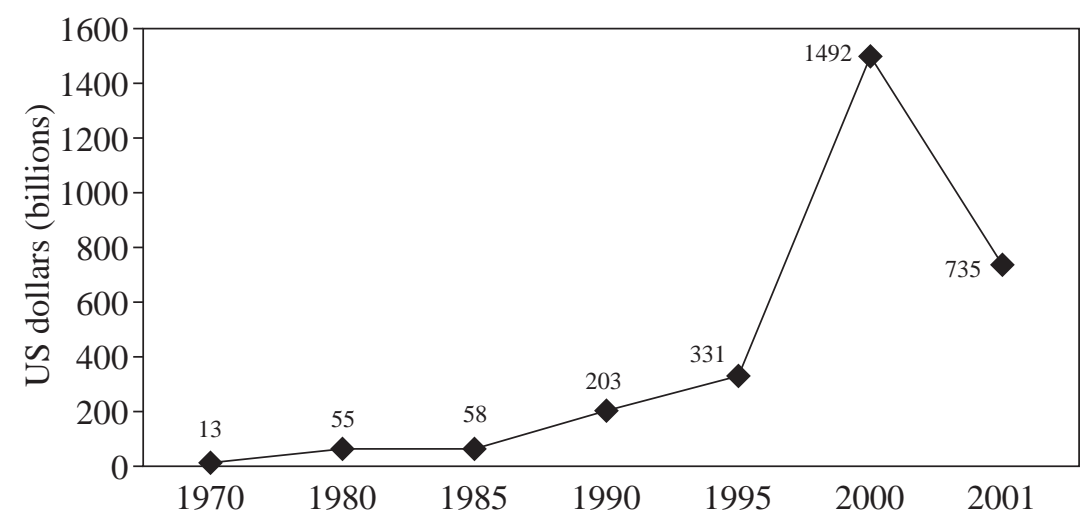

Source: UNCTAD (2002).

Figure 1.2 Annual inflows of foreign direct investment, 1970-2001, billions of US dollars

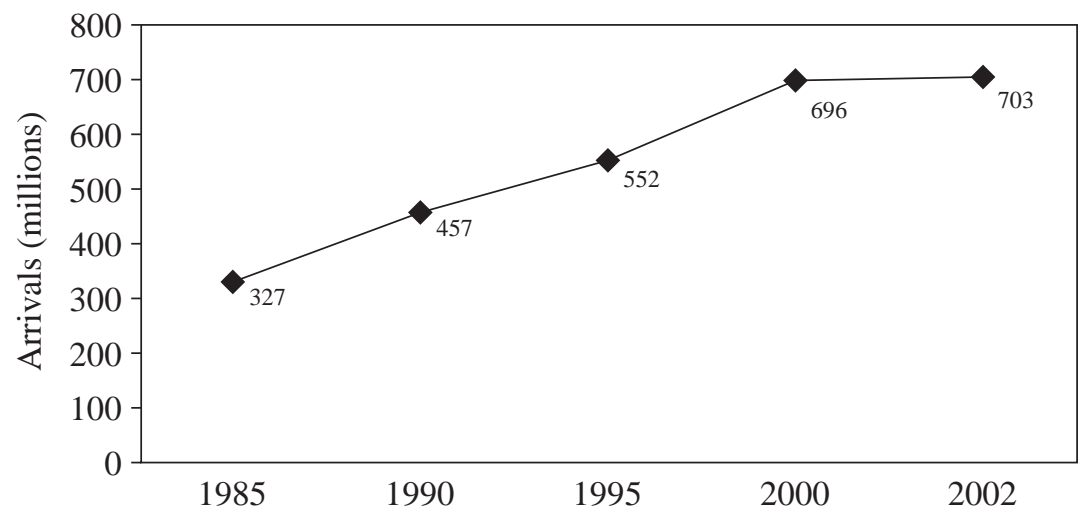

Source: World Tourism Organization (2003).

Figure 1.3 International tourism, 1985-2002, millions of arrivals

thousands of miles from affected local communities, enact similar measures, the ozone layer will continue to deteriorate and global warming will intensify, leading to harmful effects on residents in urban areas everywhere, even those whose national governments have attempted to combat environmental degradation.

The United States has long been considered as one of the most self-sufficient nations in the world, and its exports as a percentage of gross domestic product 
Table 1.3 Growth in the number of immigrants, 1990-2000

\begin{tabular}{lrrcc}
\hline & 1990 & 2000 & Number & Per cent \\
\hline World & 154.0 & 174.8 & 20.8 & 13.5 \\
More developed countries & 81.4 & 104.1 & 22.7 & 27.9 \\
Less developed countries & 72.5 & 70.7 & -1.8 & -2.6 \\
Least developed countries & 11.0 & 10.5 & -0.05 & -4.9 \\
Africa & 16.2 & 16.3 & 0.1 & 0.03 \\
Asia & 50.0 & 49.8 & -0.02 & -0.04 \\
Europe & 48.4 & 56.1 & 7.7 & 15.8 \\
Latin America & 7.0 & 5.9 & -1.1 & -15.0 \\
North America & 27.6 & 40.8 & 13.2 & 48.0 \\
Oceanic & 4.8 & 5.8 & 1.0 & 22.8 \\
\hline
\end{tabular}

Note: Figures are in millions.

Source: United Nations Population Division, 2002.

Table 1.4 Immigrants as a percentage of a nation's total population, 2000

\begin{tabular}{ll}
\hline United Arab Emirates & 74 \\
Kuwait & 58 \\
Jordan & 40 \\
Israel & 37 \\
Singapore & 34 \\
Saudi Arabia & 26 \\
Switzerland & 25 \\
Australia & 25 \\
New Zealand & 23 \\
Canada & 19 \\
United States & 10 \\
\hline
\end{tabular}

Source: United Nations Population Division, 2002.

(GDP) were only about 10 per cent in 2001, compared with 43 per cent in Canada, 35 per cent in Germany, 29 per cent in France, 27 per cent in Great Britain and 11 per cent in Japan. The stock of FDI in the United States in 2000 was the equivalent of about 12 per cent of its GDP, compared with 34 per cent in Great Britain, 28 per cent in Canada, 25 per cent in Germany, 21 per cent in France, and 1 per cent in Japan. ${ }^{27}$ Nonetheless, when measured in dollar terms, the United States is the world's leading importer, exporter, foreign direct inves- 


\section{INTERNATIONAL SECTOR}

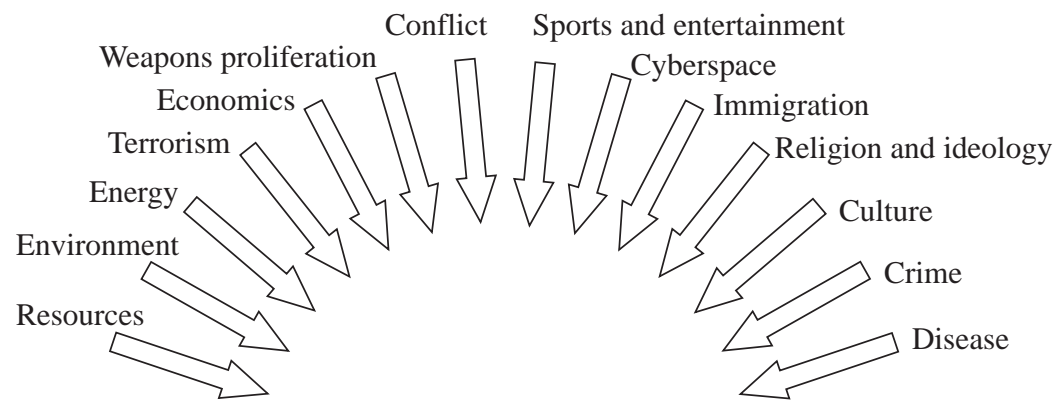

MUNICIPALITIES

Figure 1.4 International events transforming life in urban regions

tor, recipient of FDI, provider of international tourists, and leading recipient of spending by foreign visitors (see Table 1.5). It is the world's only superpower, but it is incapable of building a jet fighter or an automobile or a computer without substantial component parts and resources provided by many other nations around the world. The Department of the Treasury issues US dollars, but once in circulation, two-thirds of the currency finds its way to individuals and governments located outside the United States. ${ }^{28}$ The movement of motor vehicles and aircraft and the heating of homes and offices would also be extremely difficult without other countries providing more than 50 per cent of all petroleum products used in the USA each year. Vaclav Smil stresses the need for the world community of nations to develop alternative energy sources such as solar and wind power. He points out that solar radiation reaching the earth every year is equal to nearly 14000 times the current global total primary energy supply, and the ability to convert one per cent of all wind energy would be ten times greater than the total installed in all fossil-fuel, nuclear and hydroelectric stations in 2000. Unfortunately, the technology allowing these conversions to be made in mass quantities may still be decades away, and humanity remains highly dependent on non-renewable fossil fuels for energy, with less than 5 per cent of the global population situated in the United States expending about 27 per cent of annual primary energy usage worldwide. ${ }^{29}$ In the entertainment sector, Hollywood would also be in dire financial straits without the nearly 60 per cent of box office revenues which are generated outside US borders. ${ }^{30}$

Americans are also painfully aware about how unrest and grievances abroad can be translated into carnage and death in New York City or the Washington, 
Table 1.5 The United States and globalization

World's leading importer

(\$1.41 trillion in 2002)

World's leading exporter

( $\$ 973$ billion in 2002)

World's leading foreign direct investor

(\$1.52 trillion in 2002)

World's leading host nation for foreign direct investment

(\$1.35 trillion in 2002)

World's leading holder of foreign assets

(\$6.4 trillion in 2002)

World's leading host nation for foreign-owned assets

(\$8.8 trillion in 2002)

World's leading source of international tourists

(56.4 million in 2002 vs. 60.9 million in 2000)

World's number three recipient of international tourists

(41.9 million in 2002 vs. 51.0 million in 2000)

World's leading nation for spending by foreign tourists

( $\$ 66.5$ billion in 2002 vs. $\$ 82.4$ billion in 2000)

World's leading host nation for immigrants

(one million documented and undocumented per year)

DC area. Terrorism and international crime affect most villages, towns, and neighborhoods around the planet, with organized crime alone accounting for perhaps 3 per cent or more of total annual global production. Jeffrey Robinson estimates that international drug trafficking alone accounts for 2 per cent of global GDP, and this does not even include child prostitution, money laundering, gambling, racketeering, counterfeiting, arms trafficking and other illicit activities associated with organized crime. ${ }^{31}$ Diseases are also no respecter of national or regional political boundaries. Many of the major diseases now inflicting humanity were not even identified three decades ago, including AIDS, the HIV virus, Ebola, Hepatitis C, SARS, and the West Nile virus, and just in the period 1976-98, the World Health Organization (WHO) identified nearly 40 new diseases in humans. ${ }^{32}$ Most of these diseases had their origins in some of the remotest and rural parts of the planet, but within months or years they had spread to most of the world's major cities, piggybacking on 
the record movement of goods and people across national boundaries. As Richard Preston points out, 'a hot virus from the rain forest lives within a 24hour plane flight from every city on earth.' ${ }^{33}$ In his emphasis on 'global life systems,' Robert P. Clark documents the complexity and interconnectedness of ecosystems, emphasizing that the European expansion after 1500 helped to globalize the gene pool of humans, food and diseases, and that humans today share 65 diseases with dogs (including whooping cough), 45 to 50 with cattle (including small pox, tuberculosis and measles), 46 with sheep and goats, 42 with pigs, 35 with horses and 26 with poultry. ${ }^{34}$ Some diseases, including many that began initially in animals, have had horrific effects on human society, with the influenza pandemic of 1918-19 claiming over 20 million lives globally, and AIDS responsible thus far for 28 million fatalities and 40 million additional infections, with 5 million new HIV cases identified in 2003 alone. ${ }^{35}$ As André-Jacques Neusy suggests, in

a world where people and economies are increasingly interdependent, health risks are not self-contained. Consequently, the health in both high and low-income countries is increasingly dependent on how global health issues are managed in the world. These issues include control of infectious and chronic diseases, rising social inequalities and humanitarian crises caused by warfare, biochemical terrorism, environmental hazards and mass-migration to urban areas. ${ }^{36}$

The information and communication technologies (ICT) revolution is also accelerating the process of globalization. The human information base may be doubling every half decade. The School of Information Management and Systems at the University of California at Berkeley, in a report entitled 'How Much Information?,' has calculated that humanity stored about five exabytes (a billion gigabytes) of new information on paper, film, and optical or magnetic media in 2002, double what was stored just three years earlier. These five exabytes are equivalent to all the words ever spoken by humans since the dawn of civilization. ${ }^{37}$ Alvin Toffler has postulated that illiteracy will not be the major challenge of the twenty-first century; rather, the ability to learn, unlearn, and relearn will be the major task facing societies around the world. ${ }^{38}$ With transformations in human society occurring so rapidly, many are worried that they or their children will be unable to keep pace, and are concerned that ultimately they will be counted among the digital 'have nots' instead of the digital 'haves.'

Globalization, when combined with unprecedented technological change identified with the New Economy, has provoked rather ambivalent feelings among both urban and rural dwellers around the world. Without any doubt, the notion of the pervasive influence of the New Economy was greatly exaggerated during the period of the rapid increase in the value of 'dot.com' companies. However, the following statement made by the New Economy 
Task Force is still credible: 'The information technology revolution has expanded well beyond the cutting edge high-tech sector. It has shaken the very foundations of the old industrial and occupational order, redefined the rules of entrepreneurship and competition, and created an increasingly global marketplace for a myriad of goods and service. ${ }^{39}$ For example, the creation and expansion of the World Wide Web was a phenomenon of the 1990s, and the first US web page was not even created until 1992. The impact of the Internet has increased exponentially since that time and has had a profound impact on many societies around the world ${ }^{40}$ As an illustration, the 'e-choupals' project in India is currently serving 18000 villages and provides a computer and Internet service in a central location in each village, permitting local farmers to check futures prices globally and locally before taking their commodities to market. They are also given immediate access to local weather conditions, new soil-testing techniques, and other expert knowledge intended to increase their productivity. ${ }^{41}$

In an extensive 2003 survey conducted by the Pew Research Center for the People and the Press, a majority of respondents in 35 of the 44 nations covered had a favorable view toward at least four aspects of globalization: (1) growing trade and business ties; (2) faster communications and travel; (3) growing availability of foreign culture; and (4) the wide variety of products available from different parts of the world. ${ }^{42}$ In more than half of these nations, six of every ten respondents deemed globalization to be good or somewhat good. In 41 nations, majorities perceived trade and business ties as good for their countries and good for their families, including 96 per cent of respondents in Vietnam, 93 per cent in the Ivory Coast, and 90 per cent in Nigeria. ${ }^{43}$ Thomas Friedman observes that India and China, with two-fifths of the world's population, have staked their futures on globalization, emphasizing education, infrastructure modernization and international trade, among other priorities. He predicts that by 2010 there will be many more Internet users in those countries than in the United States. ${ }^{44}$ According to the Pew survey, young people are more likely to be favorable toward globalization, whereas those over 50 are more opposed or at least more skeptical. On the other hand, many perceive that globalization helps certain countries more than others, 'foreign' is still viewed as a negative word by many of those surveyed, and immigration to one's country is rarely viewed in positive terms. ${ }^{45}$ Broadly speaking, as underlined by A.G. Hopkins, the

advocates of capitalism and free trade see globalization as a positive, progressive force generating employment and ultimately raising living standards throughout the world. Those opposed to globalization perceive it as a means of expropriating the resources of poor countries by drawing them into debt, encouraging the use of sweated labor, and accelerating environmental degradation 
all within a contemporary world in which one-fifth of humanity takes home four-fifths of its income. ${ }^{46}$

Critics of globalization are to be found both on the political left and the political right. On the left, Maude Barlow and her compatriots in Canada lament the loss of national sovereignty and the subjugation of the environment and workers' rights to the demands of powerful MNCs ${ }^{47}$ On the right, Patrick J. Buchanan in the United States laments that free trade and liberal immigration policies have cost millions of jobs for native-born Americans and are relegating the nation to a 'developing-country' status. ${ }^{48}$ Similar arguments have been rendered by leftist groups in Europe and by rightwing proponents such as Jean-Marie Le Pen in France and the Northern League in Italy. The political left also tends to identify globalization with the United States and contends that US political and business leaders are intent on exporting the American way of life and homogenizing culture worldwide so that it reflects American values and generates profits for USbased corporations.

Globalization also has a distinctly political dimension and is affecting the ability of local elected officials to shape the futures of their municipalities. At the beginning of 2004, 148 nation states were members of the World Trade Organization (WTO), and 184 were affiliated with both the World Bank and the International Monetary Fund (IMF). An additional 30 nations or territories have also been granted 'observer status' at the WTO. In the name of freer trade and investment, national governments have agreed to adopt measures which limit the policy prerogatives of their regional and local governments. This is an especially sensitive issue in federal systems where intermediate governments such as states and provinces, as well as some local governments, operate within their own constitutionally guaranteed areas of jurisdiction.

Similar restrictions are found when national governments become members of regional groupings such as the European Union (EU) and the North American Free Trade Area (NAFTA). The EU can trace its roots back to the 1950s and expanded from six to nine members in 1973, from nine to 12 between 1981 and 1986, from 12 to 15 in 1995, and from 15 to 25 in May 2004. NAFTA has only three members, the United States, Canada, and Mexico. It went into effect in 1994 and will be fully implemented in 2008. A major controversy has erupted in North America as NAFTA's Chapter 11, which is intended to provide corporations with the right of establishment and 'national treatment' in Canada, the United States, and Mexico, has repeatedly attempted to limit what state, provincial, and local governments in North America's three federal systems can do in exercising authority to protect the workplace and the environment.

Jagdish Bhagwati posits that there are two great forces characterizing the twenty-first century: globalization and the growing civil society. The big 
question is whether they can coexist in partnership or face continuing confrontation. The other question is how well prepared municipal governments are to articulate the interests of civil society in protecting and enhancing the interests of their local constituents. ${ }^{49}$ James Rosenau adds that we live in an era of shifting boundaries, weakened states and proliferating non-governmental organizations, and over time we have developed local, provincial, national, transnational, international, and global 'levels of community.' Within this complicated setting, there are growing interactions of globalizing and localizing forces and divergent tendencies leading at times to integration and at other times to fragmentation. In effect, there is a plurality of governing actors and new patterns are evolving concerning interactions between governments and society. ${ }^{50}$ With this in mind, the impact of international and regional pacts on the decision-making latitude of municipal leaders is likely to increase in light of the expansion of the EU from 15 to 25 member-states in 2004, the anticipated completion of the WTO's Doha Development Round in 2005, and the targeted implementation of the Free Trade Area of the Americas (FTAA) in 2005.

Joseph Schumpeter's notion of creative destruction is also more relevant in the current period of globalization than when he was writing about it many decades ago. During the past several years in the United States, roughly 550000 to 600000 new businesses have been created annually, but almost as many close down each year. Approximately 30 per cent of private sector jobs in the United States may also change dramatically each year, either being newly created, terminated, or requiring a substantial change in job requirements and expectations. Manufacturing in the 1950s employed up to 35 per cent of the US private sector workforce, a figure which had dwindled to little more than 11 per cent by mid-2004. ${ }^{51}$ This drop in manufacturing jobs as a percentage of overall employment is even more significant because in 2001, salaries and benefits per full-time worker in manufacturing averaged 54000 dollars, versus only 45600 dollars for the private sector in general. ${ }^{52}$ In the period between August 2000 and December 2003, 2.8 million manufacturing jobs were lost, primarily attributable to a slow-growing economy, outsourcing, and the relocation of corporate jobs overseas. ${ }^{53}$ Unionization rates have also plummeted from the 35 per cent range in the early 1950 s to 13.2 per cent of all jobs in 2002 and only 8.5 per cent of jobs in the private sector. ${ }^{54}$

The fortunes of individual communities may also vary significantly, with the Silicon Valley region in northern California enjoying a ten-fold increase in jobs in the period between 1980 and 2000, whereas manufacturing jobs in Detroit, Newark, St. Louis and various other metropolitan regions decreased alarmingly during the same period. Joel Kotkin adds that the New Economy in the United States has not only been unkind to a broad array of places, but also a number of economic sectors such as ranching, lumbering, fishing, 
farming, textiles, automobiles, and manufacturing in general. ${ }^{55}$ Even in Silicon Valley, often viewed worldwide as the 'model' for local economic development in an era where the ITC sector is becoming much more prominent, fortunes can change rapidly. In 2001, the unemployment rate dipped into the one per cent range in Silicon Valley, but two years later Santa Clara County, the heart of Silicon Valley, was suffering from an unemployment rate well above 8 per cent, far higher than the national and California averages. ${ }^{56}$ At the same time, residents of the area faced housing prices which were among the highest in the world, clogged freeways, a deteriorating public school system and municipal and state government fiscal problems unparalleled since the end of the Second World War. State, provincial and local governments from other parts of the United States and Canada have also been 'poaching' in Silicon Valley, attempting to convince companies to move their operations or at least expand elsewhere in order to lower their costs of doing business. However, this poaching is not limited to the boundaries of North America, for many high-tech jobs in Silicon Valley and its counterparts elsewhere in the Western world have been relocated to India, China and other nations which can provide skilled labor in rich abundance but at relatively low wage rates. Forrester Research, a US consultant firm, predicts that 3.3 million US jobs and 136 billion dollars in wages will be moved offshore over the next 15 years to countries such as India, China, Russia and the Philippines, with the ICT sector leading the initial exodus overseas. ${ }^{57}$

In effect, cities around the world are involved in inter-urban competition, especially in the economic domain. ${ }^{58}$ Some of this competition may be healthy, but some is also very short-sighted, duplicative, and wasteful. Whether they like it or not, cities have been tossed into the cauldron of creative destruction. For centuries, many of the important cities of Europe and the Middle East rose to greatness because of the power base of their respective nation states, combined with their favorable location along seas, rivers, or caravan routes. ${ }^{59}$ Location near oceans or other waterways is no longer nearly as important, even though cities continue to engage in 'place' marketing. Distance, time and location have become less important in an era of unprecedented transportation and communication innovations. Even the smallest of cities in Western countries are no more than one or two airplane stops from most other major urban areas around the world. Satellite and Internet connections have also theoretically equalized the gathering and dissemination of critical information between a New York City and a Moose Jaw, Saskatchewan. Cities have become entrepreneurial zones, with the largest being the nodes for international finance, but some also represent what Saskia Sassen terms 'a new geography of centrality and marginality,' especially in the United States. ${ }^{60}$ The so-called best and brightest in a society are to be found within blocks of some very disadvantaged people, especially those with little formal education, recent immigrants and 
those facing a variety of physical and emotional challenges. In New York City, a world-renowned municipality with tremendous aggregate wealth, 44 per cent of families have few or any assets at all, three times the national average in the United States. ${ }^{61}$ As UN-Habitat points out, there are often lines of stratification between people in major cities, with the costs and benefits of globalization unevenly distributed both within and between cities. It adds that 'homeless people are living in cardboard boxes on sidewalks of gleaming corporate skyscrapers, whose budgets exceed those of many countries. ${ }^{62}$ Many would argue that the success of cities in the future cannot be measured in terms of total metropolitan production and spending, but rather on overall income distribution and the quality of life of its residents.

\section{CITIES IN HISTORY}

As indicated earlier, most of the world's population through history has been rural-based. Although humans have been around for millions of years, the first noteworthy urban settlements probably occurred in Mesopotamia and around Jericho a few thousand years ago, and the Greeks may have been the first to engage in systematic urban planning. Paul Bairoch estimates that cites emerged two to three thousand years after agriculture was first established by humans. ${ }^{63}$ Edward Soja postulates that Jericho may have been the first urban area capable of self-generated growth and development, with the roots of the city's development dating back as far as 8350 BC. ${ }^{64}$ Although cities were very small by today's standards back in medieval Europe, once they were developed they tended to have staying power, with an estimated 93 per cent of the cities with populations over 20000 in 1800 already in existence in 1300. ${ }^{65}$ Hohenberg and Lees add that most of the major cities in Europe were actually founded by 1300 , signifying that urban Europe was 'functionally made' many centuries ago. ${ }^{66}$ Between 1000 and 1500, cities had the major role in the diffusion of knowledge and began to draw from the countryside both people and food, much as is occurring in the developing world today. As people began to pour into European cities after 1750, terrible living conditions, a lack of proper sanitation, horrendous pollution, inadequate food supplies and the easy spread of disease among people living in close proximity resulted in deaths in these cities actually outnumbering births until the latter part of the 19th century. ${ }^{67}$ Yet in spite of unspeakable living conditions for many residents, cities remained the centers of creativity and innovation. As Peter Hall concludes:

Cities were and are quite different places, places for people who can stand the heat of the kitchen: places where the adrenalin pumps through the bodies of the 
people and through the streets on which they walk; messy places, sordid places sometimes, but places nevertheless superbly worth living in, long to be remembered and long to be celebrated. ${ }^{68}$

The Industrial Revolution stands out as a true 'break with the past' and helped to foment a tremendous growth in urbanization. ${ }^{69}$ Bairoch estimates that the number of urban residents in the world doubled between AD 1 and 1300, then doubled again between 1300 and 1800. In contrast, between 1800 and 1980, urban dwellers increased twenty-fold and we are now in the midst of another remarkable urban explosion in the developing world. ${ }^{70}$ Indeed, David C. Thorns predicts that the 'twenty-first century is likely to be dominated by urban living in a way that we have not experienced before,' adding that almost 90 per cent of the world's total population growth through 2025 will be concentrated in urban areas. ${ }^{71}$

\section{CHALLENGES F ACING THE WORLD'S CITIES}

Cities on a regional, national, and global basis are competing against one another to attract businesses, manufacturing enterprises, research and development facilities and head offices in an effort to provide well-paid jobs for local residents and in hopes of developing world-class clusters, whether these clusters be related to the auto industry, steel, textiles, energy, transportation, ICT, biotech or emerging fields linked to nanotechnology. ${ }^{72}$ Some of these cities are also formidable or potentially formidable global economic actors. A study sponsored by the US Conference of Mayors in 2001 compared the annual production in metropolitan areas in the United States with the gross domestic products of nation states. The study revealed that if city/county metro economies were individual nation states, 47 of the world's 100 largest 'national' economies and 85 of the top 150 would be situated in US metropolitan areas. ${ }^{73}$ Major cities such as New York City, with an annual local government budget approaching 45 billion dollars, also spend more annually than many national governments.

Cities are not only expanding population-wise but also territorially. Pudong near Shanghai and Shenzhen near Hong Kong were transformed over the course of a couple of decades from small towns into large metropolises with populations of 1.7 million and 7 million respectively. The average territorial size of the 100 most populated cities in the United States in 2000 was 168 square miles, more than triple the land size of the top 100 in 1950. As an example, Phoenix, Arizona was the ninety-ninth most populated US city in 1950 with 107000 people living within city limits measuring 17 square miles. Fifty years later, Phoenix ranked as the seventh largest city with 1.3 
million people living in boundaries encompassing 475 square miles. ${ }^{74} \mathrm{Be}$ tween 1982 and 1997, 25 million acres of farmland and open spaces, about the size of the state of Indiana, were developed by metropolitan governments, representing a 47 per cent increase in their territorial size. This physical expansion may boost overall urban production but may also contribute to urban sprawl, growing suburbanization, a further weakening of the central core, and a deterioration of older communities within the core and the socalled 'near' suburbs. ${ }^{75}$

Cities are at the crossroads of both globalization and the New Economy. ${ }^{76}$ Change is occurring so rapidly and various factors will affect cities in the future. Peter Drucker asserts that northern nations now live in a postcapitalist knowledge society which is far different from recent human history. He points out that during the twentieth century there was a rapid decline in the sector which had dominated society for 10000 years: agriculture. In 1900, agriculture was the largest contributor to GDP and to jobs, in stark contrast to the year 2000 when its contribution in both categories had become marginalized. ${ }^{77}$ Manufacturing in developed countries has been following the same road in terms of its contribution to jobs, and to a lesser extent, GDP. In 1900, most people in the North worked with their hands, but this fell to 50 per cent by mid-century and to less than 25 per cent at the beginning of the twenty-first century. Ageing will be yet another challenge in the more developed nations, with those over age 65 expected to constitute over half of the adult population in Japan and Germany by 2030, and with many other European societies approaching that level over the next three decades. $^{78}$

Most global trade, investment, and the movement of people are funneled through major cities. As UN-Habitat suggests, 'a country's global success rests on local shoulders.' 79 In the United States, 84 per cent of the nation's employment is concentrated in 319 metro areas. In Canada, the second largest nation in the world territorially, over half of the population and jobs is concentrated in only four broad metropolitan regions mostly sequestered close to the US border: Toronto and the Golden Horseshoe region of southern Ontario, Montreal, Vancouver and the lower British Columbia mainland, and the Calgary-Edmonton corridor. This concentration in four major centers has prompted one commentator to label Canada as primarily 'a handful of citystates. ${ }^{80}$ Many municipal leaders believe in the adage 'think globally and act locally,' while others are trying to implement 'glocalization' strategies which meld global trends with local particularities. The term glocalization may be traced to the Japanese expression 'dochakuka' which literally means global localization. ${ }^{81}$ In other words, the world is becoming more homogeneous in certain ways, but it is also becoming more heterogeneous in other ways, and global-local linkages and interaction may differ rather substantially from one 
city to the next. ${ }^{82}$ As Malcolm Cross and Robert Moore point out, features of what they call 'globalism' in the cultural domain do include McDonald's, Coca-Cola, pop singers, Hollywood film stars, sports heroes and filmmakers who are known throughout the world and whose appeal transcends both language and nationality. So, to a certain extent, globalism spreads 'Americanization' in the cultural realm, but it does not mean the homogenization of culture. Rather, regional, ethnic, religious and local cultures can still 'flourish in the face of globalism.' 83 The same is true in other aspects of life as well.

Most international immigrants also gravitate to large cities. In the United States, half of the foreign-born population resides in the Los Angeles, New York City, San Francisco, Miami and Chicago metro regions which together account for 21 per cent of the total US population. ${ }^{84}$ Forty per cent of the current residents of Miami and 31 per cent of Los Angeles' are foreign born. ${ }^{85}$ In Canada, 73 per cent of immigrants arriving between 1990 and 2000 settled in Toronto, Montreal, or Vancouver, and almost 44 per cent of all the residents of the Toronto metropolitan region were born outside Canada. ${ }^{86}$ The United States now relies on foreign-born labor for about one-sixth of its private-sector workforce, Switzerland nearly one-fifth and Australia almost one-fourth. ${ }^{87}$ In the US, new immigrants plus children born to recent immigrants accounted for almost 70 per cent of total population growth between 1990 and 2000, and high percentages are also found in Canada, Australia, and some European nations. ${ }^{88}$

In addition, many New Economy jobs are concentrated in larger cities, and some of these new immigrants have been instrumental in the transformation of local economies, such as the influence of Indian and Chinese-born entrepreneurs in Silicon Valley. In Canada, the high-technology revolution has been disproportionately centered in the very largest cities where, coincidentally, immigrants tend to congregate. ${ }^{89}$ One of every six jobs created in Canada during the 1990s was in the high-tech sector, but this increased to four of every 10 jobs in the largest cities. In 1990, 63 per cent of Canada's ICT jobs were in cities with populations close to or exceeding one million people, and this increased to 70 per cent in 2000, compared with 45 per cent of the total workforce in 1990 and 43 per cent ten years later. ${ }^{90}$

Globalization, the ICT revolution, and creative destruction have all combined in the 21 st century to greatly complicate governance and economic development in cities around the world. How cities react to the challenges highlighted by Drucker and others will probably differ from continent to continent, or even sub-region to sub-region. As Patrick Le Galès asserts, there are already noticeable policy differences between major European and US cities, with municipal leaders in the USA having greater faith in finance-driven capitalism and European municipal leaders leaning toward stronger social citizenship and relative equality among local residents. ${ }^{91}$ 
These phenomena, as well as policy alternatives available to municipal leaders, will be discussed in much greater detail in subsequent chapters. Chapter 2 will examine urban competitiveness, Chapter 3 the evolving field of municipal diplomacy, Chapter 4 the condition of urban economies and the role of new technologies, Chapter 5 new challenges to urban governance, and Chapter 6 the development of new international structures. Chapter 7 will then delve into the complicated process of strategic planning, and the final chapter will ponder both the exigencies of a world in a period of unprecedented transformation and the capacities for response available to urban governments. The global community is without a doubt becoming more interdependent, interconnected and intertwined, but much of its success or failure in bringing about greater prosperity, sustainability, and economic and political justice for the earth's inhabitants will depend on what transpires at the grassroots' level in cities around the world. 'Think globally and act locally' will certainly be recognized as one of the most enduring concepts of the 21 st century.

\section{NOTES}

1. UN Human Settlements Program, 2001, p. 6.

2. UN Department of Economic and Social Affairs, 2001, p. 5.

3. Population Reference Bureau, 'Human population: Fundamentals of growth patterns of world urbanization,' 2003, www.prb.org.

4. Ibid.

5. UN Human Settlements Program, 2001, p. 6.

6. UN Department of Economic and Social Affairs, 2001, p. 6.

7. Ibid.

8. Ibid., pp. 10 and 18.

9. Ibid.

10. Ibid., p. 8.

11. UN Human Settlements Program, 2001, p. 6.

12. US Census Bureau, 2002, and Washington Times, 28 January 2003.

13. Micklethwait and Woolridge, 2000, p. viii.

14. Held et al., 1999, p. 2.

15. Joseph S. Nye, Jr. and Robert O. Keohane, 'Introduction,' in Nye and Donahue (eds), 2000, p. 1.

16. Ohmae, 1995, pp. 100 and 143.

17. World Trade Organization, 2003, p. 10.

18. Ibid., p. 7.

19. UNCTAD, 2002, pp. 1 and 4.

20. Ibid.

21. Sappenfield, 2003.

22. World Tourism Organization, 2003, pp. 1-2.

23. Speech by Francesco Frangialli, Secretary-General of the World Tourism Organization, on the occasion of the inauguration of the ITB, Berlin, 16 March 2002.

24. UN Department of Economic and Social Affairs, Population Division, 2002, p. 1.

25. Ibid., p. 11.

26. International Herald Tribune, 13 March 2002. 
27. These export and FDI statistics were compiled by the Organisation for Economic Cooperation and Development (OECD) in cooperation with various UN-affiliated agencies.

28. This estimation is made by the US Federal Reserve Board. See the Washington Post, 18 January 2000, p. E1.

29. Smil, 2002, pp. 126-32.

30. Los Angeles Times, 27 July 2003.

31. Robinson, 2000, p. 337.

32. Wall Street Journal, 8 July 2003, p. B1.

33. Clark, 2001, p. 106.

34. Ibid., pp. 102 and 104.

35. UNAIDS/WHO, 2003, p. 3.

36. Neusy, 2003, p. 3.

37. Klinkenbourg, 2003.

38. Toffler, 1970.

39. Progressive Policy Institute, 1999, Introduction.

40. Berners-Lee, 1999.

41. New York Times, 1 January 2004.

42. Pew Global Attitudes Project, 2003.

43. Ibid.

44. 'Terrorism may have put sand in its gears but globalization won't stop: Interview with Thomas L. Friedman,' Yale Global, 30 January 2003.

45. Pew Global Attitudes Project, 2003.

46. A.G. Hopkins, 'Introduction,' in Hopkins, 2002, p. 9, and International Herald Tribune, 13 March 2002, p. 6.

47. Barlow and Clarke, 2001.

48. Buchanan, 2002.

49. Bhagwati, 2002, pp. 2-7.

50. Rosenau, 1999, especially pp. 287, 293, and 295.

51. Bureau of Economic Analysis, US Department of Commerce (2004).

52. Popkin, 2003, p. 17.

53. US National Association of Manufacturers, and New York Times, 3 January 2004.

54. US Bureau of Labor Statistics (2004).

55. Kotkin, 2000, pp. 9 and 184.

56. Los Angeles Times, 8 August 2003.

57. Gongliff, 2003.

58. Camagni, 2002, pp. 2395-411, and Jensen-Butler et al., 1997.

59. Rugman and Moore, 2001, p. 65.

60. Sassen, 1998, p. xxv.

61. Kotkin, 2000, p. 23.

62. UN-Habitat, 2001.

63. Bairoch, 1988, pp. 74 and 493.

64. Soja, 2000, p. 27.

65. Bairoch, 1988, p. 153.

66. Hohenberg and Lees, 1985, pp. 1 and 340.

67. Bairoch, 1988, pp. 240-42.

68. Hall, 1998, p. 989.

69. Bairoch, 1988, pp. 500-501.

70. Ibid., pp. 501-502, and 510.

71. Thorns, 2002, p. 1.

72. Uldrich, 2002, p. 16, and Aeppel, 2000, p. R40.

73. US Conference of Mayors, 2001.

74. US Department of Commerce, census 2000 data.

75. Wall Street Journal, 9 July 2001, pp. A2 and A17.

76. Agarwal, 2000, p. 6.

77. Drucker, 2003, p. 199.

78. Ibid., p. 201. 
79. UN Human Settlements Program, 2001.

80. Francis, 2002.

81. Czarniawska, 2002, p. 12, and Kantor, 1995, p. 24.

82. Czarniawska, 2002, p. 14, and Bairoch, 1988, pp. 515-17.

83. Malcolm Cross and Robert Moore, 'Globalization and the new city,' in Cross and Moore (eds), 2002, p. 2.

84. 2000 US census data featured in the Los Angeles Times, 7 February 2002, p. A11.

85. US Department of Commerce, census 2000 data.

86. Statistics Canada, census 2001 data, and McIsaac, 2003, p. 59.

87. Economist, 31 March 2001, p. 15.

88. Camarota, 2001.

89. National Post, 28 September 2002.

90. Statistics Canada, The Daily, 31 July 2003.

91. Le Galès, 2002, p. 275. 